\title{
Studies on Glucosaminidase
}

\section{TESTICULAR $N$-ACETYL- $\beta$-GLUCOSAMINIDASE AND $N$-ACETYL- $\beta$-GALACTOSAMINIDASE}

\author{
BY J. W. WOOLLEN, R. HEYWORTH AND P. G. WALKER \\ Biochemistry Department, Institute of Orthopaedics, Royal National Orthopaedic Hospital, \\ Stanmore, Middlesex
}

(Received 26 May 1960)

After the use of $p$-nitrophenyl $N$-acetyl- $\beta$-Dglucosaminide as a substrate for $N$-acetyl- $\beta$ glucosaminidase (Borooah, Leaback \& Walker, 1961), the substrate $p$-nitrophenyl $N$-acetyl- $\beta$-Dgalactosaminide has now been used to study the activity of $N$-acetyl- $\beta$-galactosaminidase. An extract of ram testis was used in this investigation as a convenient source of $N$-acetyl- $\beta$-glucosaminidase. $N$-Acetyl- $\beta$-galactosaminidase activity was present in the extract. Comparison of the properties of the two activities in this preparation indicate that both are associated with the same enzyme site.

Preliminary accounts of this work have appeared (Heyworth, Borooah \& Leaback, 1957; Woollen, Heyworth \& Walker, 1959).

\section{MATERIALS AND METHODS}

Substrates and inhibitors. Phenyl and $p$-nitrophenyl $N$ acetyl- $\beta$-D-glucosaminide were prepared according to Leaback \& Walker (1957) and the corresponding galactosaminides according to Heyworth, Leaback \& Walker (1959). The $N$-acetylhexosamines were prepared by the method of Roseman \& Ludowieg (1954). $N$-Acetylgalactosamine was chromatographically pure (Heyworth \& Walker, 1958). Its aqueous solutions were estimated by the method of Aminoff, Morgan \& Watkins (1952) with $N$-acetylglucosamine as the standard. 2-Acetamido-2-deoxygluconolactone and 2-acetamido-2-deoxygalactonolactone were prepared according to Findlay, Levvy \& Marsh (1958).

Enzyme preparation. Except where otherwise stated the freeze-dried ram-testis extract (Benger Ltd., Holmes Chapel, Cheshire) was dissolved in aqueous $0.1 \%$ crystallized bovine-plasma albumin (Armour Ltd., Hampden Park, Eastbourne, Sussex) (see Results section).

Estimation of enzyme activities. Except where indicated, solutions of enzyme $(0.1 \mathrm{ml}$.) and substrate were mixed in a total volume of $1.0 \mathrm{ml}$. of $0.05 \mathrm{M}$-citrate buffer, $\mathrm{pH} \mathrm{4.5}$, and incubated for $30 \mathrm{~min}$. at $37^{\circ}$. Liberated phenol was estimated by the procedure of Pugh, Leaback \& Walker (1957). Liberated $p$-nitrophenol was estimated by the method of Boroosh et al. (1961), modified by the use of $0.2 \mathrm{M}$-borate buffer, pH 9.8 (Clark \& Lubs, 1916), in place of 0.25 M-sodium carbonate. The reasons for this substitution are given below. Phenol did not interfere in the estimation of $\boldsymbol{p}$-nitrophenol under these conditions.

\section{RESULTS}

\section{Photolysis of p-nitrophenyl $\mathrm{N}$-acetylhexosaminides in alkaline medium}

In the assay procedure of Borooah et al. (1961) there was a slow liberation of $p$-nitrophenol from the substrates after the addition of $0.25 \mathrm{M}$-sodium carbonate if tubes were exposed to daylight (Fig.1) or u.v. light $(365 \mathrm{~m} \mu)$. No such liberation occurred in the dark or in artificial (tungsten) light. The addition of $0.2 \mathrm{M}$-borate buffer, $\mathrm{pH} \mathrm{9.8}$, in place of sodium carbonate stopped the enzyme reaction, giving a final $\mathrm{pH}$ of $\mathbf{9 \cdot 2}$. This $\mathrm{pH}$ was sufficiently high for the complete conversion into the anionic form of any $p$-nitrophenol liberated by the enzyme but sufficiently low to cause negligible further breakdown of the substrate even in daylight.

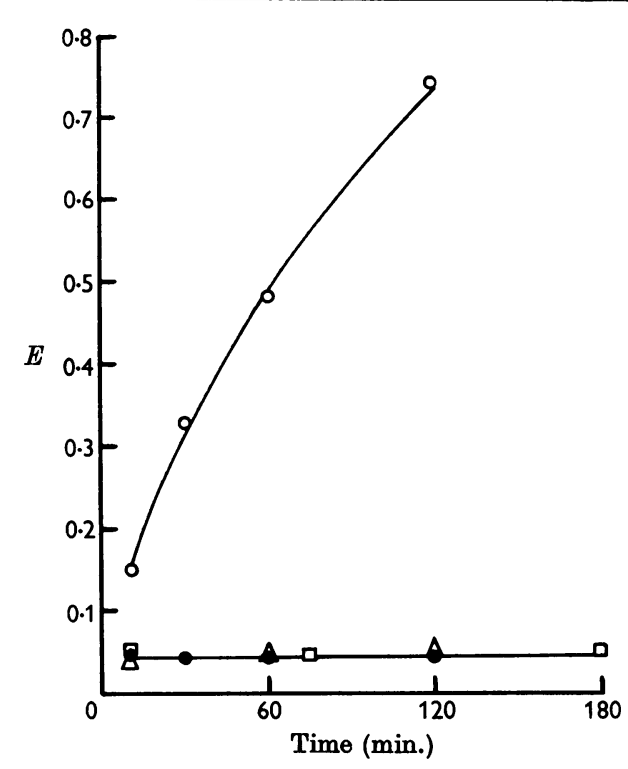

Fig. 1. Photolysis of $p$-nitrophenyl $N$-acetylglucosaminide (2 ml., 3.6 mM in 0.05 M-citrate buffer, $\mathrm{pH} 4.5$ ) treated with $4 \mathrm{ml}$. of (1) $0.25 \mathrm{M}$-sodium carbonate, in daylight $(O)$, in darkness (O), in tungsten light ( $\square)$, and (2) $0.2 \mathrm{M}$-borate buffer (pH 9.8) in daylight $(\triangle)$. 
Effect of enzyme concentration and time of incubation

The $N$-acetylglucosaminidase activity of a solution of the freeze-dried testis extract $(0 \cdot 1 \%, \mathrm{w} / \mathrm{v})$ made in $0.1 \%$ albumin was about $15 \%$ higher than that of a solution made in water (Fig. 2). Activity was not increased further by raising the concentration of albumin to $1 \%(w / v)$. The difference in activity was not due to instability of the enzyme in the absence of added protein under conditions of assay, since both solutions showed constant rates of hydrolysis over periods of incubation up to $1 \mathrm{hr}$. Fig. 2 shows constant specific activity in the presence of $0.1 \%$ of albumin and a constant absolute loss of activity in the absence of albumin, over a fourfold range of enzyme concentration. Although activity lost on dilution with water was restored by subsequent addition of albumin to the assay mixture, cysteine (4 mM) had no effect and the loss in activity was unaltered with different preparations of the enzyme, substrate, buffer or distilled water; it was therefore not due to contamination of one of the reagents with traces of some toxic impurity (cf. Dixon \& Webb, 1958). The loss of activity on dilution could also be prevented by using a solution of the non-ionic detergent Triton X-100 (0.2\%, v/v; Charles Lennig and Co. Ltd., London, W.C. 1) and the effect was therefore

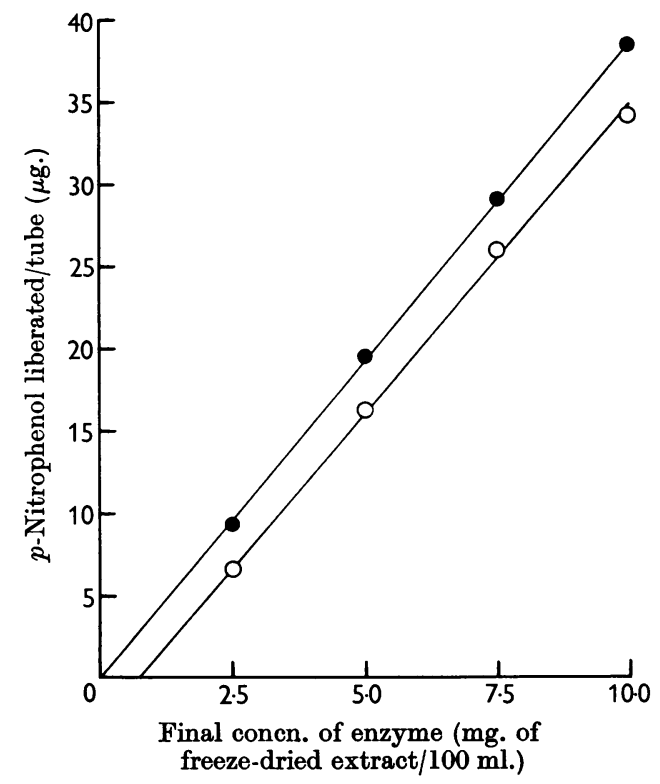

Fig. 2. Effect of enzyme concentration on activity in the absence and presence of albumin. Substrate: 3.6 mM-pnitrophenyl $N$-acetylglucosaminide. The enzyme solutions $(0.1 \mathrm{ml} . / \mathrm{ml}$. of incubation mixture) were made up in and diluted further with either water $(O)$ or $0.1 \%$ albumin (O). For other conditions see text. probably due to surface inactivation. A similar effect was found with $N$-acetylgalactosaminidase activity.

\section{Effect of $\mathrm{pH}$}

Fig. 3 shows the effect of different $\mathrm{pH}$ values over the range 3.5-6.0 on the rates of hydrolysis of the two $p$-nitrophenyl substrates relative to the individual maximum activities. $N$-Acetylgalactosaminidase shows a single $\mathrm{pH}$ optimum of $4 \cdot 3$, whereas $N$-acetylglucosaminidase shows peaks at $\mathrm{pH} 4.45$ and $4 \cdot 7$. The peak at $\mathrm{pH} 4.7$ was found in two other experiments when albumin was omitted from the assay mixture; it was not found with a partially purified preparation of the testis extract (Borooah et al. 1961).

A $\mathrm{pH}$ of 4.5 was selected for subsequent experiments, all of which involved comparative measurements of $N$-acetylglucosaminidase and $N$-acetylgalactosaminidase activities.

\section{Effect of substrate concentration}

The effect on the rate of hydrolysis by different concentrations of each of the four substrates was measured at $\mathrm{pH} 4.5$ over at least an eightfold concentration range. The $K_{m}$ and $V_{\max }$ values for the substrates, at $\mathrm{pH} \mathrm{4.5}$, are shown in Table 1 . The value of $V_{\max }$ for each $N$-acetylglucosaminide substrate was seven times as great as the value for the corresponding $N$-acetylgalactosaminide. The

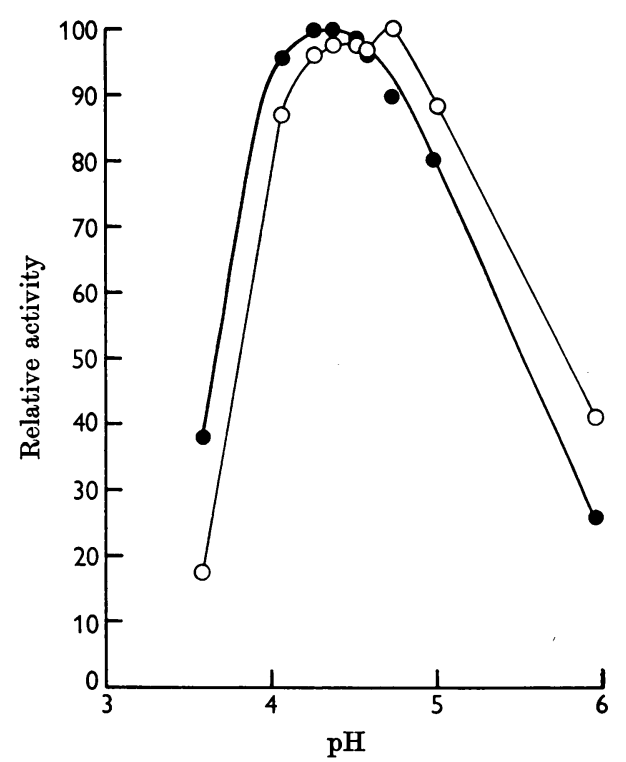

Fig. 3. Effect of $\mathrm{pH}$ on $N$-acetylglucosaminidase and $N$ acetylgalactosaminidase activities. Activities are plotted relative to the highest activity (100), with $3.6 \mathrm{~mm}-p$-nitrophenyl $N$-acetylglucosaminide and $0.06 \%(w / v)$ of enzyme (O); or 2.2 mM-p-nitrophenyl $N$-acetylgalactosaminide and $0.24 \%$ of enzyme (O). For other conditions see text. 
Table 1. $K_{m}$ and $V_{\text {max. }}$ values for substrates at $\mathrm{pH} 4 \cdot 5$

Values of $K_{m}$ and $V_{\max }$. were determined by the method of Lineweaver \& Burk (1934). For preparation of enzyme solution and conditions of assay, see text. $V_{\max }$. values are expressed as $\mu$ moles of substrate hydrolysed/ mg. of freeze-dried testis extract/30 min.

\section{Substrate}

$p$-Nitrophenyl $N$-acetylglucosaminide $p$-Nitrophenyl $N$-acetylgalactosaminide Phenyl $N$-acetylglucosaminide

Phenyl $N$-acetylgalactosaminide

\begin{tabular}{cc}
$\begin{array}{c}\text { Concn. range } \\
(\mathrm{mM})\end{array}$ & \multicolumn{1}{c}{$\begin{array}{c}K_{m} * \\
(\mathrm{mM})\end{array}$} \\
$0 \cdot 73-5 \cdot 84$ & $1 \cdot 18 \pm 0 \cdot 04(12)$ \\
$0 \cdot 18-1 \cdot 46$ & $0 \cdot 28 \pm 0 \cdot 01(12)$ \\
$1 \cdot 0-16 \cdot 0$ & $2 \cdot 94 \pm 0 \cdot 12(4)$ \\
$1 \cdot 0-16 \cdot 0$ & $1 \cdot 22(2)$
\end{tabular}

* Mean \pm S.E. (no. of results).

Table 2. Effect of fractionation of the enzyme on $\mathrm{N}$-acetylglucosaminidase and $\mathrm{N}$-acetylgalactosaminidase activities

Activities were measured with either $2 \cdot 2 \mathrm{mM}$ - $p$-nitrophenyl $N$-acetylglucosaminide or $N$-acetylgalactosaminide as substrate. For other conditions see text.

$\begin{array}{ccc}\text { Enzyme preparation } & \begin{array}{c}N \text {-Acetyl- } \\ \text { glucosaminidase } \\ \text { (\% of activity of } \\ \text { untreated preparation) }\end{array} & \begin{array}{c}\text { Ratio } N \text {-acetyl- } \\ \text { glucosaminidase/ } \\ N \text {-acetylgalactos- } \\ \text { aminidase activity }\end{array} \\ \begin{array}{c}\text { Untreated } \\ \left(\mathrm{NH}_{4}\right)_{2} \mathrm{SO}_{4} \text { fractions* }\end{array} & 100 \cdot 0 & 4 \cdot 6 \\ 0-30 \% & & \\ 30-40 \% & 6 \cdot 1 & 4 \cdot 4 \\ 40-50 \% & 33 \cdot 2 & 4 \cdot 4 \\ 50-60 \% & 15 \cdot 4 & 4 \cdot 4 \\ & 1 \cdot 5 & 4 \cdot 4\end{array}$

* Precipitated between the indicated limits of $\%$ saturation with $\left(\mathrm{NH}_{4}\right)_{2} \mathrm{SO}_{4}$.

Table 3. Adsorption of $\mathrm{N}$-acetylglucosaminidase and $\mathrm{N}$-acetylgalactosaminidase activities by calcium phosphate gel

Residual activities in the supernatants were measured with either $2.2 \mathrm{~mm}$ - $p$-nitrophenyl $N$-acetylglucosaminide or $N$-acetylgalactosaminide as substrate. For other conditions see text.

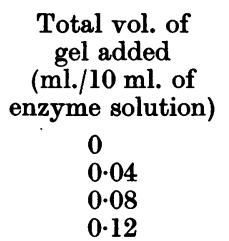

Total vol. of gel added enzyme solution)

$0 \cdot 12$

$N$-Acetyl-
glucosaminidase
(\% of initial activity)
100
89
69
35

Ratio $N$-acetylglucosaminidase/ $N$-acetylgalactosaminidase activity $4 \cdot 9$ $5 \cdot 1$

$5 \cdot 2$ values of $K_{m}$ for the $N$-acetylglucosaminide substrates agree with those of Borooah et al.(1961) obtained with partially purified testicular extract.

\section{Attempts to separate N-acetylglucosaminidase and $\mathrm{N}$-acetylgalactosaminidase}

Fractionation with ammonium sulphate. A solution of the testis extract in water was treated with successive amounts of saturated ammonium sulphate solution at $4^{\circ}$. The precipitated fractions were redissolved in water and dialysed for 3 days at $4^{\circ}$ against water. Samples of the original solution and each of the fractions were made $0.1 \%$ with albumin and the two activities were measured under standard conditions with $2 \cdot 2 \mathrm{~mm}-p$-nitrophenyl $N$-acetylhexosaminides (Table 2). There was no indication of any separation of the activities.

Fractionation with calcium phosphate gel. An aqueous solution of the enzyme was treated with successive amounts of calcium phosphate gel (Keilin \& Hartree, 1951). At each stage a sample of the supernatant was made $0.1 \%$ with albumin and the two activities were measured under standard conditions (Table 3). $N$-Acetylglucosaminidase and $N$-acetylgalactosaminidase were adsorbed in stages up to $65 \%$ but there was no separation of the two activities.

Partial inactivation. The untreated enzyme and two ammonium sulphate fractions were preincubated at $56^{\circ}$ and $\mathrm{pH} \mathrm{4.5}$ for periods up to $6 \mathrm{~min}$. The solutions were then made $0.1 \%$ with albumin and the two activities measured (Table 4). $N$ Acetylglucosaminidase and $N$-acetylgalactosaminidase were decreased to about $30 \%$ of their initial values without any change in the ratio of the two activities. 
Table 4. Effect of partial inactivation on $\mathrm{N}$-acetylglucosaminidase and $\mathrm{N}$-acetylgalactosaminidase activities

An untreated enzyme preparation and two $\left(\mathrm{NH}_{4}\right)_{2} \mathrm{SO}_{4}$ fractions (cf. Table 2) derived from it were preincubated in $0.05 \mathrm{M}$-citrate buffer, $\mathrm{pH} 4.5$, at $56^{\circ}$ for the periods indicated. Residual activities were assayed with either 2.2 mM-p-nitrophenyl $N$-acetylglucosaminide or 2.2 mM-p-nitrophenyl $N$-acetylgalactosaminide as substrate. For other conditions see text.

$\begin{array}{lccc}\text { Enzyme preparation } & \begin{array}{c}\text { Time of } \\ \text { preincubation } \\ (\text { min. })\end{array} & \begin{array}{c}N \text {-Acetyl- } \\ \text { glucosaminidase } \\ \text { (\% of initial activity) }\end{array} & \begin{array}{c}\text { Ratio } N \text {-acetyl- } \\ \text { glucosaminidase/ } \\ N \text {-acetylgalactos- } \\ \text { aminidase activity }\end{array} \\ \text { Untreated } & 0 & 100 & 4 \cdot 4 \\ & 3 & 48 & 4 \cdot 4 \\ \left(\mathrm{NH}_{4}\right)_{2} \mathrm{SO}_{4} \text { fractions } & 6 & 22 & 4 \cdot 3 \\ 30-40 \% & 0 & 100 & \\ & 3 & 64 & 4 \cdot 2 \\ 40-50 \% & 6 & 33 & 4 \cdot 5 \\ & 0 & 100 & 4 \cdot 1 \\ & 3 & 62 & 4 \cdot 4 \\ & 6 & 36 & 4 \cdot 4 \\ \end{array}$

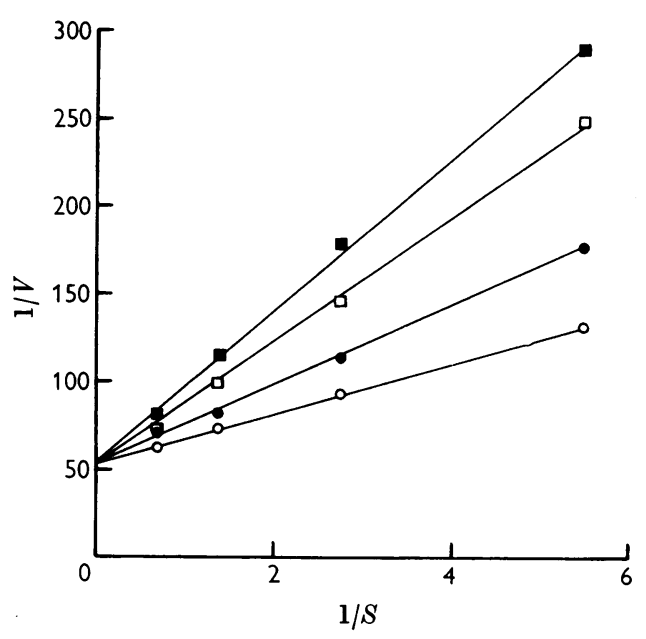

Fig. 4. Effect of different substrate concentrations on the rate of hydrolysis of $p$-nitrophenyl $N$-acetylgalactosaminide. With no addition (O), in the presence of $2 \mathrm{~mm}$ phenyl $N$-acetylglucosaminide (O), $5 \mu \mathrm{M}$-2-acetamido2-deoxygluconolactone ( $\square$ ) and $15 \mathrm{~mm}-N$-acetylglucosamine (ם). $S$, Substrate concentration (mM); $V, p$-nitrophenol liberated/tube ( $\mu \mathrm{g}$.$) .$

\section{Competitive behaviour}

$N$-Acetylglucosamine, 2-acetamido-2-deoxygluconolactone and phenyl $N$-acetylglucosaminide acted competitively with $p$-nitrophenyl $N$-acetylgalactosaminide (Fig. 4). The corresponding galactosamine compounds also competed with this substrate and all six compounds competed with $p$ nitrophenyl $N$-acetylglucosaminide. The similarity of the $K_{i}$ values, determined by the method of Lineweaver \& Burk (1934) and measured against each $p$-nitrophenyl substrate (Table 5), indicates that under these conditions, the compounds com-
Table 5. $K_{i}$ values of various competing substances

Each value is an average of two results, determined by the method of Lineweaver \& Burk (1934), from experiments in which competition with (1) $p$-nitrophenyl $N$-acetylglucosaminide $(0 \cdot 73-5.84 \mathrm{~mm})$ or (2) $p$-nitrophenyl $N$ acetylgalactosaminide $(0 \cdot 18-1 \cdot 46 \mathrm{~mm})$ was studied.

Competitive inhibitors

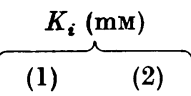

$\begin{array}{lll}N \text {-Acetylglucosamine } & 5 \cdot 2 & 6 \cdot 9 \\ N \text {-Acetylgalactosamine } & 2 \cdot 5 & 2 \cdot 6 \\ \text { 2-Acetamido-2-deoxygluconolactone } & 0 \cdot 0037 & 0 \cdot 0035 \\ \text { 2-Acetamido-2-deoxygalactonolactone } & 0 \cdot 0012 & 0 \cdot 001 \\ \text { Competing substrates } & & \\ \text { Phenyl } N \text {-acetylglucosaminide } & 2 \cdot 8 & 3 \cdot 6 \\ \text { Phenyl } N \text {-acetylgalactosaminide } & 0 \cdot 6 & 0 \cdot 8\end{array}$

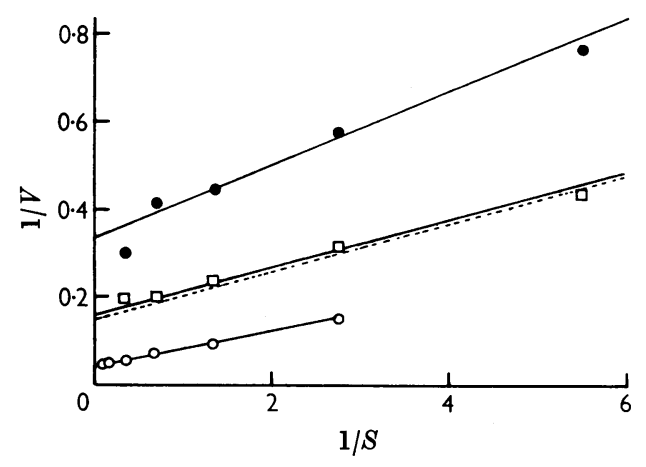

Fig. 5. Effect of different substrate concentrations on the rate of hydrolysis of $p$-nitrophenyl $N$-acetylglucosaminide (O), of $p$-nitrophenyl $N$-acetylgalactosaminide (O) and of equimolar mixtures of the two $(\square)$. For conditions see text; $V$, total $p$-nitrophenol liberated ( $\mu \mathrm{g}$.); $S$, total substrate concentration (mM); - - , theoretical plot for an equimolar mixture of competing substrates derived from the individual substrate results. 
pete identically with $p$-nitrophenyl $N$-acetylglucosaminide and $p$-nitrophenyl $N$-acetylgalactosaminide.

\section{Competing substrates}

Fig. 5 shows the results obtained in a study of enzymic hydrolysis of the two $p$-nitrophenyl substrates separately and in equimolar mixtures over an eightfold concentration range. The values of $K_{m}$ and $V_{\text {max. }}$ derived from experiments with the individual substrates were used to calculate the theoretical line (dotted) for the total hydrolysis expected from equimolar solutions of two substrates competing for one enzyme site (Thorn, 1949; Foster \& Niemann, 1951). The agreement between observed and calculated lines for the mixed substrates was very good.

\section{DISCUSSION}

The choice of $p$-nitrophenyl $N$-acetylgalactosaminide as a substrate was based on previous experience with the corresponding $N$-acetylglucosaminide. In spite of its lower rate of hydrolysis, the solubility $(0.15 \%, w / v)$ of this substrate and the sensitivity of the estimation procedure of $p$-nitrophenol allowed a sufficiently wide range of substrate concentrations for the accurate determination of $V_{\text {max. }}, K_{m}$ and $K_{i}$ values.

The photolysis of the $p$-nitrophenyl substrates, experienced in daylight when the enzyme reaction was stopped with sodium carbonate, was eliminated by the selection of a buffer of suitable $\mathrm{pH}$ and molarity in place of sodium carbonate solution.

The use of $0.1 \%$ albumin solution for diluting the enzyme overcame the loss of specific activity on dilution and the variation in duplicate assays which were experienced in the early stages of this work. Triton X-100 $(0.2 \%, v / v)$ had the same protective effect. The behaviour observed was very similar to that shown by highly purified preparations of prostatic acid phosphatase (Tsuboi \& Hudson, 1955).

Attempts to separate $N$-acetylglucosaminidase and $N$-acetylgalactosaminidase by fractionation with ammonium sulphate or calcium phosphate gel or by partial heat inactivation were unsuccessful and suggested that the two activities might be associated with the same enzyme protein.

Kinetic experiments were therefore undertaken to test if both activities were associated with one enzyme site. The two $N$-acetylhexosamines, 2acetamido-2-deoxyhexonolactones and phenyl $N$ acetylhexosaminides behaved competitively with both $p$-nitrophenyl substrates. The similarity of the $K_{i}$ values for each competitor obtained by measurement against either $p$-nitrophenyl substrate is strong evidence that each substrate (and hence each competitor) is combining with the same point or points on the enzyme surface. This interpretation was confirmed by the good agreement of the experimental plot of the substrate concentration curve for mixed substrates with that calculated on the assumption of competition at a single site.

For two other glycosidases evidence has been obtained that the specificity at C-4 is not absolute. Marsh \& Levvy (1958) showed by partial inactivation and by the use of competitive inhibitors that a single enzyme was responsible for the $\beta$-glucuronidase and $\beta$-galacturonidase activities in preparations from limpet and mammalian tissues. Helferich and his co-workers [for references see Veibel (1950)] failed to separate the $\beta$-glucosidase and $\beta$-galactosidase activities of almond emulsin either by extensive purification or by various attempts at differential inactivation. Kinetic measurements of the hydrolysis of $\beta$-glucosides and $\beta$-galactosides seemed to indicate that the two glycosidases were different (Veibel, 1950) but more detailed studies of competition between substrates and of specific inhibition (cf. Conchie \& Levvy, 1957) are needed in order to reach a final conclusion.

The lack of specificity of $N$-acetylhexosaminidase for configuration at C-4 is interesting in view of the suggestion that $N$-acetyl- $\beta$-glucosaminidase acts on the oligosaccharides formed from hyaluronic acid by the actions of hyaluronidase and $\beta$-glucuronidase (Linker, Meyer \& Weissman, 1955). Oligosaccharides containing $N$-acetylglucosamine or $N$-acetylgalactosamine are obtained from hyaluronic acid or from chondroitin and chondroitin sulphate by the action of a single enzyme in preparations of testicular hyaluronidase. The corresponding oligosaccharase shows therefore a lack of specificity analogous to that of the polysaccharase.

\section{SUMMARY}

1. $p$-Nitrophenyl $N$-acetylgalactosaminide has been used as a substrate to measure the $N$-acetylgalactosaminidase activity of a ram-testis extract.

2. The photolysis of $p$-nitrophenyl $N$-acetylglucosaminide, which occurs in daylight after the enzymic hydrolysis has been stopped by adding sodium carbonate, was overcome by the use of borate buffer, $\mathrm{pH} \mathbf{9} \cdot \mathbf{8}$.

3. The presence of $0.01 \%$ of albumin or $0.02 \%$ of Triton X-100 in the enzymic solutions prevented a loss of specific activity on dilution of the enzyme.

4. No separation of the activities of $N$-acetylglucosaminidase and $N$-acetylgalactosaminidase was achieved by fractionation with ammonium sulphate or calcium phosphate gel, or on partial heat inactivation.

5. The $K_{i}$ values of the competing substances $N$-acetylglucosamine, 2-acetamido-2-deoxyglucono- 
lactone and phenyl $N$-acetylglucosaminide and of the corresponding galactosamine derivatives were measured. For each substance the value obtained with $p$-nitrophenyl $N$-acetylglucosaminide as substrate was almost the same as that obtained with $p$-nitrophenyl $N$-acetylgalactosaminide.

6. The competition of $p$-nitrophenyl $N$-acetylglucosaminide and $p$-nitrophenyl $N$-acetylgalactosaminide for one enzyme site was confirmed by an experiment with mixtures of these substrates.

We acknowledge the kind gifts of 2-acetamido-2-deoxygalactonolactone from Dr G. A. Levvy and of freeze-dried ram-testis extract from Benger Ltd. This work was assisted by grants from the Research Fund of the University of London and the Nuffield Foundation.

\section{REFERENCES}

Aminoff, D., Morgan, W. T. J. \& Watkins, W. M. (1952). Biochem. J. 51, 379.

Borooah, J., Leaback, D. H. \& Walker, P. G. (1961). Biochem. J. 78, 106.

Clark, W. M. \& Lubs, H. A. (1916). J. biol. Chem. 25, 479.

Conchie, J. \& Levvy, G. A. (1957). Biochem. J. 65, 389.

Dixon, M. \& Webb, E. C. (1958). Enzymes. London: Longmans, Green and Co. Ltd.
Findlay, J., Levvy, G. A. \& Marsh, C. A. (1958). Biochem. J. 69, 467.

Foster, R. J. \& Niemann, C. (1951). J. Amer. chem. Soc. $73,1552$.

Heyworth, R., Borooah, J. \& Leaback, D. H. (1957). Biochem. J. 67, $21 \mathrm{P}$.

Heyworth, R., Leaback, D. H. \& Walker, P. G. (1959). J. chem. Soc. p. 4121.

Heyworth, R. \& Walker, P. G. (1958). Abstr. Comm. 4th int. Congr. Biochem., Vienna, no. 1-48, p. 7.

Keilin, D. \& Hartree, E. F. (1951). Biochem. J. 49, 88.

Leaback, D. H. \& Walker, P. G. (1957). J. chem. Soc. p. 4754.

Lineweaver, H. \& Burk, D. (1934). J. Amer. chem. Soc. 56, 658.

Linker, A., Meyer, K. \& Weissmann, B. (1955). J. biol. Chem. 213, 237.

Marsh, C. A. \& Levvy, G. A. (1958). Biochem. J. 68, 610.

Pugh, D., Leaback, D. H. \& Walker, P. G. (1957). Biochem. J. 65, 464.

Roseman, S. \& Ludowieg, J. (1954). J. Amer. chem. Soc. 76, 301.

Thorn, M. B. (1949). Nature, Lond., 164, 27.

Tsuboi, K. K. \& Hudson, P. B. (1955). Arch. Biochem. Biophys. 55, 191.

Veibel, S. (1950). In The Enzymes, vol. 1, p. 624. Ed. by Sumner, J. B. \& Myrbäck, K. New York: Academic Press Inc.

Woollen, J. W., Heyworth, R. \& Walker, P. G. (1959). Biochem. J. 73, $40 \mathrm{P}$.

Biochem. J. (1961) 78, 116

\title{
Mechanism of Transaminase Action
}

\author{
By T. OSHIMA \\ Department of Biophysics and Biochemistry, Faculty of Science, University of Tokyo, Tokyo, Japan \\ AND N. TAMIYA \\ School of Medicine, Tokyo Medical and Dental University, Tokyo, Japan
}

(Received 29 April 1960)

It is known that during the course of transaminase action the $\alpha$-hydrogen atom of an amino acid exchanges with a hydrogen atom of the medium water (Konikova, Dobbert \& Braunstein, 1947; Konikova, Kritzmann \& Teiss, 1942). We have found that during the reaction an exchange also occurs with the hydrogen atoms at the $\beta$ position of amino acid. This paper presents the experimental evidence for such an exchange and discusses the significance of the phenomenon for the mechanism of the transaminase reaction. A preliminary report of this work has already appeared (Oshima \& Tamiya, 1959).

\section{MATERIALS AND METHODS}

Enzyme. An alanine-glutamate transaminase preparation was obtained from pig-heart homogenate as described by Green, Leloir \& Nocito (1945). After the third ammonium sulphate precipitation and dialysis, the preparation was freeze-dried and stored at $-20^{\circ}$.

Calcium pyridoxal phosphate. Pyridoxal phosphate was prepared from pyridoxamine dihydrochloride according to the method of Wilson \& Harris (1951).

$\alpha$-Deutero-DL-alanine (DL-[2- $\left.{ }^{2} \mathrm{H}\right]$ alanine). $\alpha$-Deuteriumsubstituted DL-alanine $\left[\mathrm{CH}_{3} \cdot \mathrm{CD}\left(\mathrm{NH}_{2}\right) \cdot \mathrm{CO}_{2} \mathrm{H}\right]$ was prepared by the electrolytic reduction of $\alpha$-isonitrosopropionic acid $\left[\mathrm{CH}_{3} \cdot \mathrm{C}(: \mathrm{N} \cdot \mathrm{OH}) \cdot \mathrm{CO}_{2} \mathrm{H}\right]$ in deuterium oxide. The method 